\title{
EUROZONE CRISIS
}

\section{Marek Loužek ${ }^{*}$}

\begin{abstract}
:
The purpose of the paper is to analyse the current crisis of the eurozone. The first part explains why the eurozone is not an optimum currency area. The second part points out that euro is an intensifier of the business cycle. The third part examines the Greek crisis. The fourth part explains the inner tensions in the eurozone. The fifth part asks whether euro is suitable for the countries of Central and East Europe. The sixth part examines the debt crisis within the eurozone.
\end{abstract}

Keywords: eurozone, financial crisis, debt crisis

JEL Classification: E42, E44, E58, F34, F36

\section{Introduction}

The general public in the nineteen countries of the European Union believed politicians who promised that introduction of euro would contribute to economic growth, reduce unemployment and bring monetary stability. Today, it is clear that the introduction of euro did not succeed in preventing the constant decline of the growth of European economy and that the single currency has different impacts on the individual eurozone countries. And that is not all: it has started to be a source of instability of the global economy (Karras, 2011).

The driving force behind the European monetary unification has always been solely politics, not economics (Klaus, 2012). The political ambition has always been dominant. Euro was regarded as a useful tool for creating a political union. When looking at the economic performance of the eurozone during the first years of its existence, even the pro-European activists must admit that the high expectations of the overall economic recovery were not met and the visions that euro will increase the rate of economic growth did not come true.

When the single European currency was born in 1999, the expectations were high. Euro was expected to boost economic growth, employment and overall prosperity. And in the beginning, it seemed that the future full of prosperity and social security was becoming a reality. Fifteen years have elapsed and nothing is further from reality than a stable and healthy macroeconomic framework in the eurozone. Euro did not provide stability. On the contrary, it itself has become a source of instability (Jones, 2009).

The purpose of the paper is to analyse the current crisis of the eurozone. The first part explains why the eurozone is not an optimum currency area. The second part points out

* University of Economics, Faculty of Economics, 4, W. Churchill Sq., CZ - 13067 Prague 3 and Václav Klaus Institute, Šárecká 29, 16000 Prague 6, Czech Republic (e-mail: louzek@post.cz). 
that euro is an intensifier of the business cycle. The third part examines the Greek crisis. The fourth part explains the inner tensions in the eurozone. The fifth part asks whether euro is suitable for the countries of Central and Eastern Europe. The sixth part examines the debt crisis within the eurozone.

\section{Non-optimal Currency Area}

A monetary union can work well if the conditions for an optimum currency area are met. These conditions were defined by professor Robert Mundell (1961) in an article in the American Economic Review and they were among the achievements for which he received the Nobel prize in economics. Individual states would form an optimum currency area if: 1. they had high mutual labour mobility, 2. they had salaries with downwards flexibility, 3. they had intensive mutual trade and if 4 . there were similar natural resources available to them and there was a symmetry in the exogenous positive and negative shocks.

These conditions are not met in Europe today (Eichengreen, 1993). The mobility of labour force is relatively low in Europe and the necessary downwards flexibility of salaries and prices is virtually non-existent. The rigidity of the European labour market is sufficiently well known. The asymmetrical positive and negative shocks have been constantly reoccurring in Europe, which is not surprising at all because the eurozone countries are different (Klaus, 2004).

The size of budget transfers at the eurozone level is very small. There is a certain degree of international solidarity among the EU member states but its level is incomparable with the degree of solidarity inside the national states. Accession to the eurozone does not mean adoption of a world currency but only a regional currency so the exchange risk still remains, although its size is substantially reduced if most of the country's trade partners use the same currency (Giavazzi, 2010). The costs of monetary unification are considerably high.

The Mundell's theory of the optimum currency area was violated multiple times when euro was being introduced (Feldstein, 2012). If euro were introduced with respect for the economic theory, countries such as Ireland, Spain, Portugal, Italy, Greece, Lithuania and Latvia or Estonia should not even think of a single currency because an optimum currency area requires, among other things, a high level of flexibility of salaries and prices, including the possibility of downward changes.

Mundell considered the emergence of a single European currency to be a significant turning point of the entire international system. In his opinion, euro will disrupt the strong position of dollar. Introduction of euro can even be the most important change from the moment when dollar - after the World War I broke out - replaced the British pound in the position of the dominant world currency. Mundell considers the USD/EUR exchange rate to be the most important price in the world (Mundell, 1998).

However, a country that gives up its own currency and adopts euro, loses an exchange rate as the natural factor balancing the financial flows between the domestic economy and foreign economies and the amount of money becomes an uncontrollable variable (Friedman, 1970). Any increase of export or inflow of investments results in an increase of the amount of money in the economy; conversely, a decrease of export or outflow of capital leads to a decrease of the amount of money (Prokopijevic, 2010). 
The fact that the rate of economic growth in the eurozone countries did not increase but, conversely, decreased was not a coincidence. Since its creation, the rate of growth in the eurozone was substantially lower than that in, for example, the USA as well as than that in the "old" EU countries that refused euro for the time being. According to the European Central Bank, the long-term potential rate of growth of the eurozone is just above $1.2 \%$. That is no miraculous growth, that is the rate of a snail (Eichengreen, 2011).

Figure 1 shows the economic growth in the European Union where integration has been under way on an ongoing basis. Eurostat reconstructed data for the fifteen countries of the future eurozone since the 1950s. While the average economic growth of Western European countries was $5.8 \%$ in the $1950 \mathrm{~s}, 4.3 \%$ in the $1960 \mathrm{~s}, 3.0 \%$ in the $1970 \mathrm{~s}, 2.5 \%$ in the $1980 \mathrm{~s}$ and $2 \%$ in the $1990 \mathrm{~s}$, it was just slightly above $1 \%$ in the first decade of the 21 st century.

\section{Figure 1}

\section{Economic Growth in the EU with Ongoing Integration}

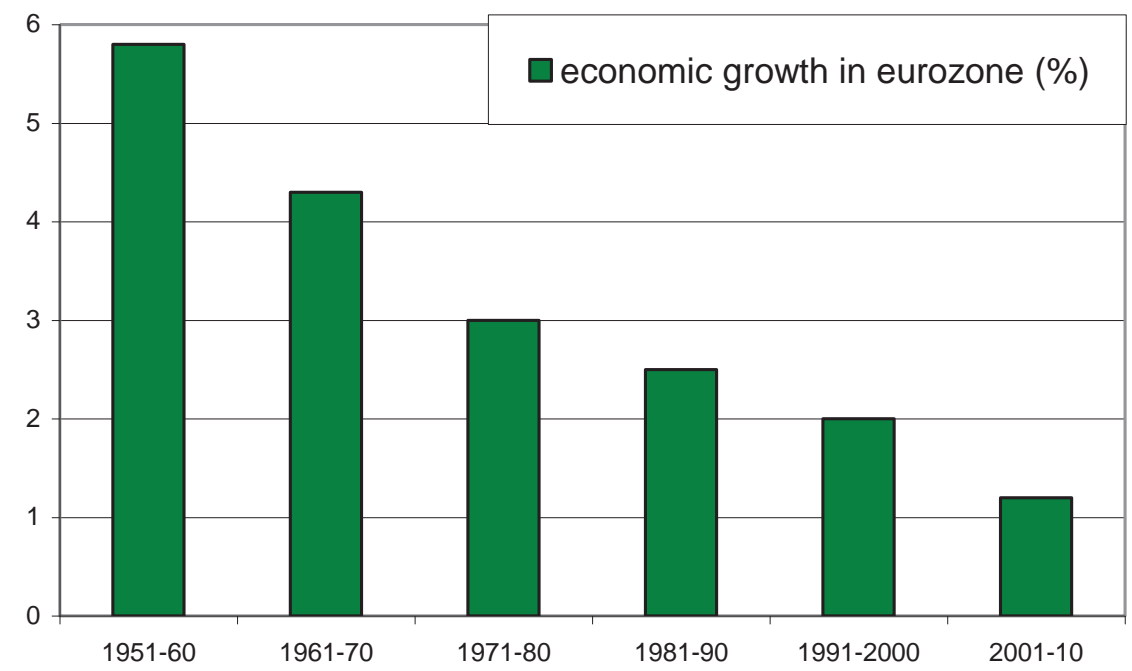

Source: Eurostat

The single currency did not meet the expectations even in the area of mutual convergence of the participating economies as concerns the growth and inflation rates. Some of the eurozone countries stopped complying with the criteria for stability of public finance that were sanctified in the Stability and Growth Pact. Today, a number of the eurozone countries do not even meet the Maastricht criterion for inflation. Conversely, the candidates are strictly required to meet the inflation criterion (Coenen, Straub, Trabant, 2012).

The differences in inflation rates inside the eurozone are another problem. As soon as the eurozone was launched, the inflation rates of the individual countries started to diverge from each other. Gradually, two groups of countries have formed, of which one group has an inflation rate that has been under the eurozone average on a long-term basis (Germany, France, Belgium and Austria), while the other group has an inflation rate 
above the average. On a long-term basis, all the other eurozone member countries except for Finland belong to the group with the long-term higher inflation rate (Bohn, Jong, 2011). The different real interest rates set economic processes in motion, some of which have a very dangerous tendency to self-boost. Low or even negative real interest rates result in the overheating of the economies of some countries and to excessive investments, the structure of which may be erroneous on top of it all. The overheating of economies has a tendency to increase the inflation rates and nominal wages in these countries (Tomšík, Šaroch, Srholec, 2005).

The different real interest rates result in increasing the gap between the current accounts of the balance of payments of the individual eurozone members. Considerable deficits or, conversely, surpluses of the current accounts of the balance of payments are gradually accumulating inside the monetary union and this result in profiling the debtor and creditor countries of the eurozone. In debtor countries, excessive credit expansion and erroneous capital allocation has taken place. This can be observed in Greece, Spain, Portugal or Ireland (Sarrazin, 2012).

The eurozone itself remains non-homogeneous (according to GDP in purchasing power parity, the most developed country of the eurozone is approximately four times as rich as the least developed). The eurozone is apparently not an optimally monetarily united area and it is also not united politically. And since the latter type of union is missing, it can hardly be the former type of union. The fact of the non-optimal political area explains why the structural faults of euro as a currency have been of such a fundamental nature right from the beginning (Hampl, 2012).

\section{Euro as an Intensifier of the Business Cycle}

The problems were by no means so obvious while a massive credit expansion was taking place in Europe. The economic growth driven by the growing indebtedness was masking the problems with flexibility quite successfully until the year 2008. Ireland, Spain and other marginal economies of the eurozone were struggling with inflation. Most of the time, the European Central Bank applied an expansionary policy of low interest rates that was favourable to countries afflicted with stagnation. However, in Ireland and Spain, the very low interest rates - below the level of the inflation rate in these countries - became something like growth hormones (Kohout, 2010).

The adaptation processes taking place within the economic and monetary union are based on the fundamental and somewhat paradoxical principle of the monetary union: one size obviously does not fit all. Interest rates are to help the eurozone members as the instruments of regulation. The ECB sets the basic interest rate according to the average economic indicators in the entire fairly heterogeneous area with the single currency (Marsh, 2009).

In the years before the introduction of euro, Hans Tietmeyer, the former president of the German central bank, warned that those member countries of an economic and monetary union, which generate a higher inflation rate than Germany can suffer from decrease of competitiveness, which (unlike in the past) it would not be possible to compensate for by currency devaluation but could only be coped with by a decrease of the domestic prices of the internationally traded goods and services or by higher unemployment (Sinn, 2010). 
During the first decade of the existence of the single European currency, there have been unusually strong fluctuations in economic activity in Europe and, understandably, these were downward fluctuations. Euro met the expectations only partially: yes, it became a currency recognised as the second world reserve currency, even a currency more important than dollar on some markets. Technically, it was and still is a success. But in economic terms, it has worked as the mightiest intensifier of the business cycle since the times of the classical gold standard (Welfens, 2011).

During the period of boom, euro helped to strengthen this boom for multiple reasons. Firstly, the monetary policy tailored to the slowly growing German economy caused intensive overheating of some other economies, particularly those of Spain and Ireland. While the economies of these countries were growing thanks to the credit bubble, most Spaniards and Irishmen did not mind this very much - except for those who wanted to buy an apartment and found out that immovable properties were too expensive for them. But the deflation of the credit bubble in the years 2008-09 was very unpleasant (Nellis, Alexiou, 2012).

\section{Figure 2}

Inflation at the Periphery of the Union

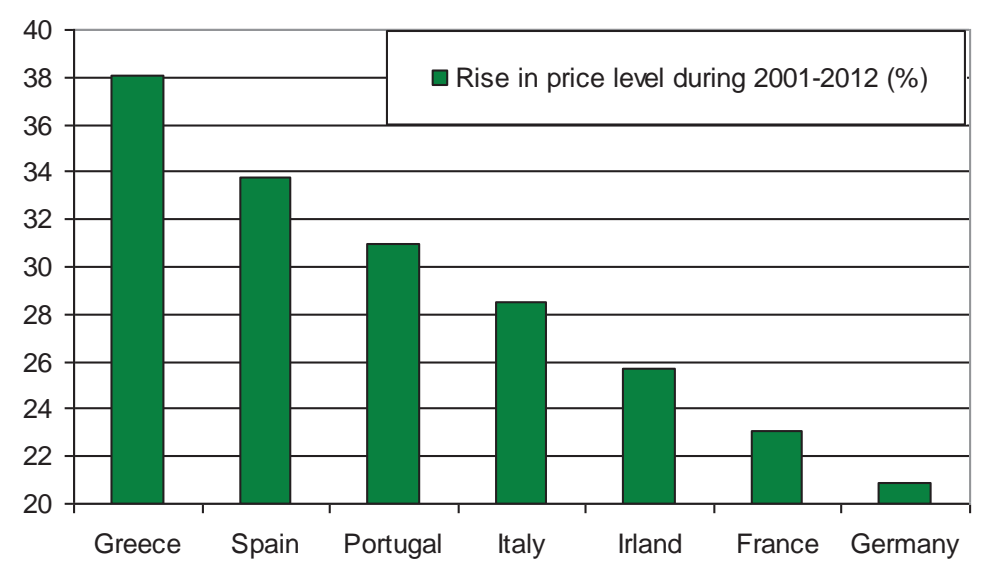

Source: Eurostat, 2013

Figure 2 shows the rise of the price level in the years 2001-2012. The ascent of the price level was most strongly taking place in Greece, Spain, Portugal, Italy and Ireland. In these countries, a head-over-heels growth was concurrently taking place, driven mainly by credits: in the years 1995-2009, the real GDP increased by $105 \%$ in Ireland, by $55.6 \%$ in Greece and by $50.2 \%$ in Spain. Conversely, in Germany where the rise of the price level was the smallest, the real GDP only increased by $16.2 \%$ in the years $1995-2009$.

In an article titled "Spanish Tragedy" (2010), Paul Krugman, a Nobel prize winner, wrote: "They need higher competitiveness - but they cannot carry out currency devaluation because they have euro. Thus, the only alternative is to decrease wages, which is desperately difficult (and creates big problems for debtors). In spite of what perhaps everyone was saying only several years ago, being a member of the eurozone does not 
provide immunity to a financial crisis. In the case of Spain (and Italy, Ireland and Greece), euro may very well contribute to deterioration of the situation" (Krugman, 2010).

The Irish economy is in the greatest need of currency devaluation but this is not possible (Ryan, 2011). It is not possible to leave the eurozone. It is legally possible but such a step would probably cause more problems to the economy concerned than it would solve. Setting aside the negative publicity and the concern about the future monetary stability, leaving euro and devaluing the old-new national currency would mean an immediate increase of the value of the obligations denominated in the new domestic currency. In other words, the public debt would increase by ten, twenty or more percent literally overnight. And this applies not only to public debts but also to private debts (De Grauwe, Ji, 2013).

Since currency devaluations are not possible in the eurozone and the countries at the Southern and Western periphery of the monetary union such as Ireland, Portugal, Spain and Greece had higher inflation rates than the group of countries from the core of the eurozone around the Federal Republic of Germany, their exchange rates were growing in real terms and they were gradually losing competitiveness in foreign trade. In the Southern wing, euro instigated wasteful consumption and speculative purchases of financial assets and properties, the value of which sharply dropped during the times of crisis (Marsh, 2009).

Problems can be caused not only by membership in the eurozone but even by the linking of a national currency to euro (Sinn, 2010). Up until 2007, Latvia was witnessing a huge inflow of capital that drove the prices of apartments and houses to astronomical heights. In addition to that, the events already known from Spain and Ireland took place: expansion of credits, particularly mortgage credits. And it was not only inflation of properties: the fixed link of the currency to euro had the consequence that CPI in Latvia increased by $17 \%$ in summer 2008 .

Then, the sobering phase came just like in the other peripheral countries of the eurozone. The prices of apartments in Riga dropped by $56 \%$ during the period from the middle of the year 2007 to the early 2009. During the second half of the year, the Latvian economy dropped by $9 \%$. In 2009, the situation really reminded the times of the Great Depression in the 1930s in many respects. Many Irishmen, Spaniards and Italians (and perhaps even members of other nations) started to be sorry about their membership in the eurozone (Kohout, 2010).

However, the Latvian central bankers did not permit even the slightest doubts about the monetary regime, which caused troubles to Argentina in 2000, to Russia 1998 and Thailand, Malaysia, Korea, Philippines and the Czech Republic in 1997. The fixed monetary anchor has the drawback that it deprives the central bank of its control over the amount of money in the economy. While the amount of money grows, nobody minds. At least in the beginning (Eichengreen, 2011).

The consumer price inflation in Latvia was between 7 and $10 \%$ in the years $2007-08$. But the wages increased by $51 \%$ during the same years! The wages in the public sector even increased by generous $61 \%$. The result was credit inflation: from the time when the link to euro was established until the beginning of the crisis in October 2008, the volume of business credits increased by $143 \%$, the volume of mortgage credits even increased by $448 \%$. The real estate speculators were rejoicing over the explosive growth of the prices of properties (Sarrazin, 2012). 
According to the data from the IMF, the GDP of the Baltic countries decreased by $13-17 \%$ in purchasing power parity in the years 2008-2009. The hard landing of the Baltic economies was not the result of a wrong fiscal policy. On the contrary, the Baltic economies were presented as examples of good financial management. The crisis was caused by a single factor, which was the credit bubble inflated by the fixed link between the currency and euro. As if economists and politicians did not learn so many times throughout the history that a fixed "anchor" of the currency exchange rate is actually a highly dangerous arrangement (Feldstein, 1997b).

Bagus (2011) argues that the eurozone has created a special case of the tragedy of the commons. The theory of the tragedy of the commons shows that with publicly owned goods there is a tendency to overdraw and that such goods gradually disappear. Euro is threatened by those member states that are trying to finance their budgets with extensive deficits and to transfer the costs of these higher deficits to others. Thus, the eurozone has an inner tendency to lose purchase power, which may result in its complete collapse.

\section{Greek Crisis}

The possibility that the bankruptcy of Greece will drag the other countries from the periphery of the eurozone with it and will result in disintegration of the entire monetary union cannot be excluded (Marsh, 2009). After the interest rates of the governmental bonds of the countries from the southern wing increased, the ECB started to buy the governmental bonds of the southern wing of the eurozone. As a result, it stopped being an independent institution entrusted with overseeing a stable currency and changed into a politicised organisation that actively intervenes in the fiscal matters of problematic states although the treaties have forbidden this up until now (Maier, 2013).

Greece is insolvent and it is not only a distant, theoretical threat. In 2008, the sovereign debt of Greece was $99 \%$ of its GDP; in 2013, the debt rose to $169 \%$ of its GDP. The Greek government is forced to make drastic cuts in its budget. Financial markets are not willing to buy more Greek bonds. The disadvantage of a public debt is that it must often be "rolled over", which means that the maturing issues must be replaced with new ones (Kouretas, Vlamis, 2010).

A moral hazard has emerged: Greek is a member of the eurozone and the eurozone will not let it fall. The bet on the moral hazard was initially successful: The European Central Bank lent 40 billion euro to Greek commercial banks for 1\% annual interest rate. Optimists are saying: if there were not for its membership in the eurozone, Greece would have already collapsed. Realists remark that if there were not for its membership in the eurozone, the financial crisis in Greece might not have occurred at all (Pavoncello, 2011).

Euro is too hard a currency for the Greek economy. This country would need a cheaper currency in order to be able to level its balance of trade and balance of payments. In 2009 the deficit of Greek's balance of trade reached 14.5\% of GDP. The deficit of the current account of the balance of payments was just a little better - it was $12.5 \%$ GDP. Under the heavy weight of the strong euro, Greece continues to wither. It would need currency devaluation just as Turkey where depreciation of lira helped during recession. However, this is not possible within the eurozone (Lynn, 2010).

And yet there is an early warning mechanism: in Greece, Latvia, Spain, the USA and other countries affected by the financial crisis, the original cause of the problems was 
excessively fast growth of bank loans. The growth of the volume of credits and money in double-digit annual percent figures is a signal of a fever for the economy. Central bankers do not want to respond because the fever is pleasant for most of the general public (Kohout, 2010).

\section{Figure 3}

\section{Greatest Debtors in the EU}

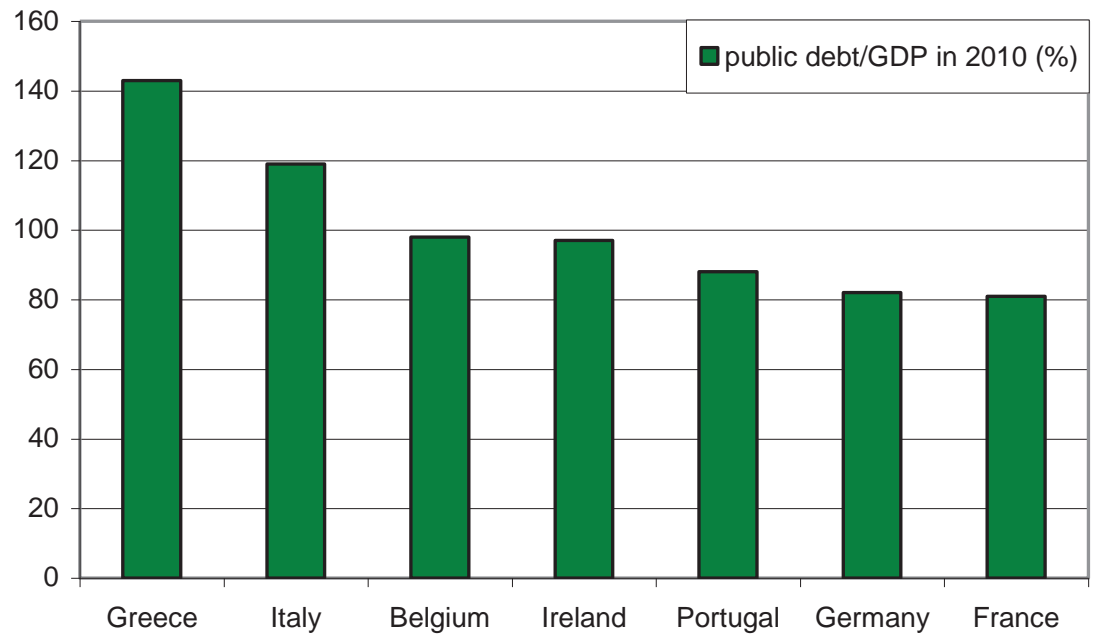

Source: Eurostat 2011

In July 2011, the leaders of the eurozone countries approved a plan, according to which the over-indebted Greece would receive, in addition to the existing 110 billion euro, another 110 billion euro in the form of cheap loans from the European Rescue Fund and through waiver of some of the debts by private investors. Private holders of Greek governmental bonds will voluntarily waive $21 \%$ value of these securities. Also, the maturity period of the bonds will be extended up to thirty years.

In October 2011, the union decided to recapitalise European banks (to increase the capital adequacy to 9\%) and to strengthen the credit capacity of the European Rescue Fund to one trillion euro. It was agreed that banks would write off half of the Greek debts. Thus, Greek has actually found itself bankrupt. Thanks to the write-offs of Greek debts, the debt of Athens should decrease by one hundred billion euro. The ECB, IMF and the European Commission all agreed with these agreements (Gros, 2013).

In February 2012, the EU provided Greece with a loan of 130 billion euro from the European Financial Stability Fund (EFSF) until 2014. This loan exceeds the extent of the former assistance provided in May 2010 (110 billion euro) as well as the extent of the voluntary write-off of the Greek debt. From private debts, creditors will voluntarily write off $70 \%$. However, the European Central Bank does not intend to write off the Greek debt owed to this bank in the amount of 50 billion euro (Whelan, 2013).

In February 2012, the ECB also announced that it would release up to one trillion new euros into the system (Maier, 2013). For a three-year loan to commercial banks, the ECB demands a one-percent interest and even the lower-quality governmental bonds of 
Spain and Italy or mortgages can be used as a security. The effect of this measure was only of short-term nature. Ultimately, the loans may prove to be a Greek gift. Cheap money will stimulate inflation and will weaken the efforts of governments to address the pressing budgetary problems.

The much-debated synchronisation of the business cycle - or, speaking precisely, its absence - was not the problem. Conversely, the asynchronous course of the business cycle perhaps even used to be an advantage because when, for example, Germany fell into recession and the rest of Europe did not, the unabated German export was able to help the economy. But when the entire Europe falls into recession synchronously, the situation of local exporters is precarious and difficult to resolve (Karras, 2011).

\section{Inner Tensions in the Eurozone}

The current economic situation of Greece, Spain, Portugal and Ireland shows the longterm and more general problem of the economic incongruity of the eurozone (Tomšík, Šaroch, Srholec, 2005). The yields of governmental bonds in Greece, Ireland, Portugal and Spain have become so high that Brussels was compelled to give help through rescue packages. The European Central Bank is buying the governmental bonds of the Southern wing of the eurozone.

The grand project aiming to stabilise Europe resulted in the exact opposite (Marsh, 2009). The monetary project, the goal of which was higher cohesion and solidarity, brought resistance and disruption. Negative sentiment against euro is taking its toll it threw off the governments in Ireland and Portugal, deepened the political vacuum in the Netherlands and Belgium and threatened the ruling parties in Finland, Germany, Spain and France (Braun, Tausendpfund, 2014).

In April 2011, even Portugal asked for financial help in its debt crisis. Thus, after Greece and Ireland, Portugal has become the third country of the eurozone, which wants to protect itself from the impending insolvency by a rescue loan. The agony of Portugal (and Greece and Ireland before that), along with the astronomical amounts, which it pays for its debts, should lead to creation of rules for a controlled bankruptcy or the restructuring of the eurozone debts (Buti, Carnot, 2012).

And yet the bankruptcy of a state is nothing unusual in the history (Reinhart, Rogoff, 2009). While Australia, France, the United Kingdom, the USA, Canada or South Korea have never experienced a state bankruptcy, Italy saw one state bankruptcy since 1800 , and Portugal experienced six bankruptcies (and spent approximately $10 \%$ of the time in this status) over the same period. Spain failed to pay its obligations thirteen times and was found in bankruptcy for a quarter of this time. Greece went bankrupt six times but spent $51 \%$ of the time, i.e. more than one hundred years, not repaying its debts (Vitek, 2011). 


\section{Figure 4}

\section{Highest Fiscal Deficits in the EU}

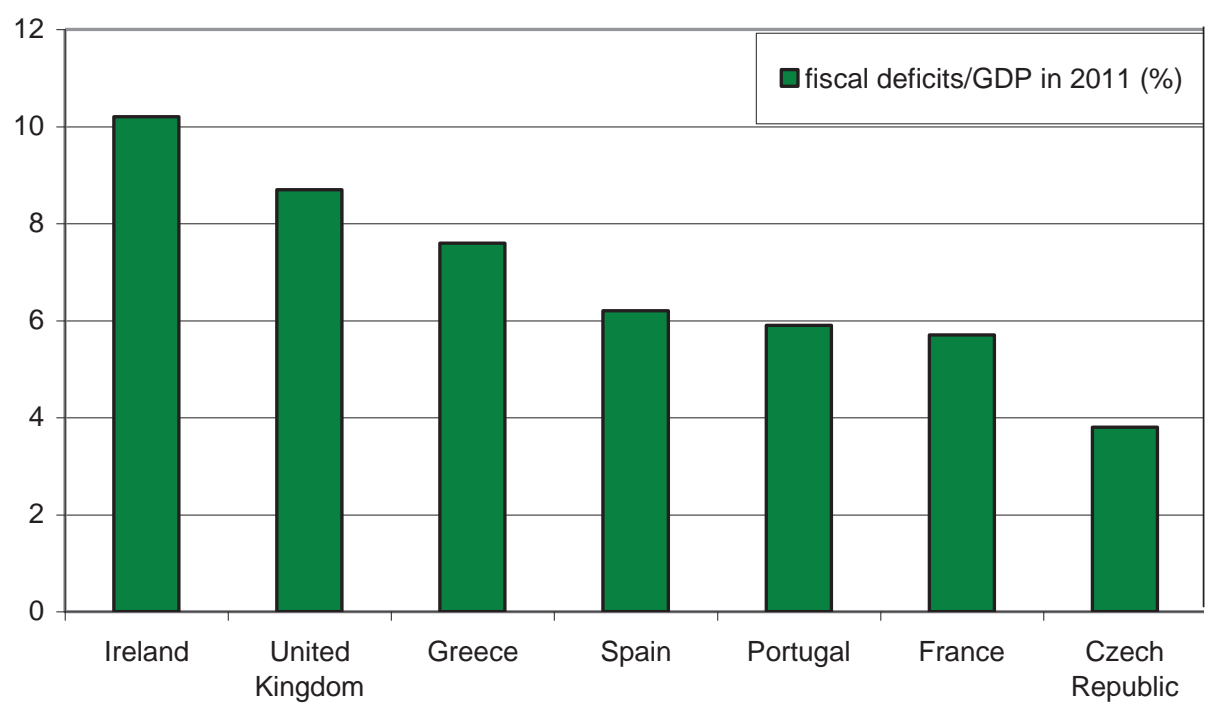

Source: OECD

The main problem of euro is the divergence of the competitive capabilities of the individual economies. The eurozone has inherent inner tensions that cannot be eliminated by any monetary or fiscal policy. It is given by the different historical development, business environment, differences in culture and education. These factors generate competitiveness (or lack thereof) and cannot be influenced on a short-term basis (Ferguson, Kotlikoff, 2000).

During the more than fifteen-year existence of the single currency, there has not been a single state whose residents could claim "yes, we have splendidly profited from euro". Euro helped Greece obtain a mask of a stable economy for a few years, which enabled this country to fall into even greater debts. Without euro, the country would also go bankrupt but it would happen sooner, with lower costs and, above all, it would be possible to devalue the currency, that is, to stimulate export and attract tourists (Kohout, 2010).

If European politicians do not approach the eurozone problem in a responsible manner, the promised help for the indebted countries will only be the first of the steps strengthening the moral hazard in the fiscal area within the eurozone and the EU. The price for that will be long-term economic stagnation of all countries and, sooner or later, an exchange rate crisis of the eurozone, accompanied by increase of inflation rate. The eurozone is not what it only recently was or seemed to be (Singer, 2010).

\section{Euro and the Countries of Central and Eastern Europe}

Many people in the countries of Central and Eastern Europe are looking forward to euro. They expect they will benefit from the stability of euro, from limitation of the exchange rate risk or from a trustworthy monetary policy. These people cannot see the reverse side 
of this monetary arrangement because it is more than clear that the transition countries need maximum flexibility and should not implement any artificial rigidities (Klaus, 2004).

The countries of Central and Eastern Europe should not act against their economic interests for political reasons. The main costs that these countries will incur will be the loss of an independent monetary policy that should be - for transition economies where tumultuous structural changes are taking place and for countries with a lower economic standard - distinctly different from a monetary policy suitable for the stable Western member countries. There is no rational economic reason for all countries to have the same interest rate (Sarrazin, 2012).

Transition economies are found in a constant process of real appreciation and there is no way of achieving it within a fixed exchange rate, while complying with the inflation and interest rate criteria of the Maastricht Treaty (laid down in the Stability and Growth Pact). There is a risk that the exchange rate will be set outside its long-term balanced position because the convergence process of these economies will not yet be completed at the time when they enter the eurozone. The result will be an unsuitable level of currency exchange rate (Lorca-Susino, 2010).

Convergence of the relative price level in the countries of Central and Eastern Europe with that of more developed countries, for example, with the eurozone average can take place through two channels: either the exchange rate is strengthened, which makes their goods and services more expensive for other countries - while they themselves do not feel this increase of expensiveness. Or through inflation differential - a situation where they would have a higher inflation rate than the eurozone. However, inflation makes all goods more expensive not only for other countries but also for them (Janáčková, 2004).

In Slovenia, which acceded to the eurozone in January 2007, inflation rose from 1.6\% before the accession to $5.7 \%$ at the end of the first year of its membership and to $6.9 \%$ in March 2008. This country then had the highest inflation rate in the entire eurozone in spite of the fact that its relative price level had come close to $80 \%$ of the eurozone average at the time of the accession. Long-term differences in inflation rates have impacts on the real economy.

As a result of convergence of the price level, the adoption of euro - that is, the loss of the exchange rate channel for convergence - would drive the inflation rates of the countries of Central and Eastern Europe up (some estimates from the Czech National Bank banking board mention a possible increase of inflation rate by up to 3.5-4 per cent), which is incompatible with long-term compliance with the Maastricht criterion. The same applies to other Central European countries with a low relative price level (Janáčková, 2010).

Slovakia which joined the eurozone five years ago has not experienced any significant pro-growth impulse. While the average growth of Slovakia five years before the accession was $7 \%$, now five years after the accession, the average growth of Slovak economy is $2 \%$. The National Bank of Slovakia estimates the annual savings resulting from reduction of transaction costs at mere $0.3 \%$ of GDP. The savings from reduction of foreign exchange risk are estimated by the National Bank of Slovakia at $0.02 \%$ of GDP, particularly due to the low extent to which hedging against foreign exchange risk is used.

The countries of Central and Eastern Europe should not accede to the eurozone before the eurozone solves its fiscal problems, before the eurozone proves its higher growth potential, before the relative difference of the relative price levels gets smaller (so that there is no risk of increase of inflation rate as a result of fixed exchange rate after 
the accession), before the eurozone becomes an optimum currency area and before they find out with certainty about the direction in which the eurozone will head in the future.

The rigidity of the monetary union and the growing implicit macroeconomic imbalance will block the real convergence and will create "transfer economies" (this is what happened to East Germany after the unification), which, however, will have to survive without high fiscal transfers because these are not available in the current EU. Therefore, transition countries should not hurry into the eurozone (Klaus, 2004).

Janáčková (2010) argues that, moreover, the eurozone even does not want the countries of Central and Eastern Europe; it does not wish any further massive enlargement. Neither the eurozone countries nor the European Central Bank are interested in enlarging the eurozone by admitting another group of countries - which are, moreover, poorer and are still in the catching-up phase. Besides Greece, which acceded in 2001, only Slovenia, Slovakia and Estonia have accomplished successful accession so far.

Lithuania hit a strict refusal when it exceeded the Maastricht criterion for inflation by $0.07 \%$ - which is well below the limit for a statistical error. This gave the European Central Bank a welcome pretence to reject Lithuania. Nevertheless, it subsequently became apparent that Lithuania was really unable to maintain its low inflation rate on a longer-term basis because immediately after that, its inflation rate soared up to $10 \%$.

The European Central Bank is right in saying that after adoption of euro, the preaccession inflation rates of the countries of Central and Eastern Europe would be untenable. This has also been proved by the experience of half of the eurozone countries - the more quickly growing and catching-up ones - which did meet the inflation criterion before its launch but ceased to do so after they found themselves in the eurozone. Demanding longterm guarantees of compliance with this criterion from new members seems to be absurd in such a situation (Janáčková, 2010).

\section{Debt Crisis}

Both politicians and technocrats like to claim that it is not possible for countries to leave the eurozone. The house of the single currency is entered through a spectacular main entrance; and the backdoor disappears. But economic history does contain events which used to be unthinkable and which eventually really happened - be it the departure of Britain from the gold standard in 1913 or the disintegration of the Soviet monetary empire into fifteen separate currencies after 1991 (Marsh, 2009).

The crisis of the eurozone showed that the fact alone that euro is used as the legal tender in a certain country does not tell very much about the quality of its economic policy, the extent of imbalances or long-term competitiveness. The formerly heretic or dissident statement is today regarded as a basically trivial finding. The question is why we first have to hit the wall with tremendous force for things obvious before the impact to become generally accepted (Hampl, 2010).

Euro brought the decrease of some transactions costs (for example, the revenues of banks in Slovakia decreased after introduction of euro, partially due to euro), particularly lower and less variable inflation. However, that is no huge benefit for those who had been able to maintain low and stable inflation even without euro, while not losing monetary policy as an adjusting tool as well as an exchange rate as an additional market whip for their own economic policy. 
Even before the introduction of euro, the fiscal rules were rightfully criticised as a very dangerous combination of non-flexible rules without a sufficiently strong mechanism for their enforcement. Nevertheless, mainly due to the will of Germany which did not want to abandon strong Mark for a weaker currency, these rules were adopted. It is ironic that it is exactly Germany (along with France) that has today become the country which has succeeded in ignoring these rules without being punished (Singer, 2010).

The basis of the Maastricht criteria was the thought that the countries in the monetary union should have their public finances in order and that their respective inflation rates should not be much different from each other. Fiscal discipline and convergence of the inflation levels are necessary conditions for a single monetary policy to be suitable for a group of countries. The question is whether it is sensible to enter a monetary union whose members are unable to comply with these conditions (Janáčková, 2004).

It is alarming that the Maastricht criteria transformed into what is referred to as the Stability and Growth Pact stopped being adhered to inside the eurozone (Wolf, 2012). Recurring problems with compliance with the limits for public finance deficit were encountered by the large countries of the eurozone - Germany, France and Italy in recent years. These countries even enforced such modifications to the Stability Pact that some analysts said that this pact was dead (Wittmann, 2011).

Economic theory has long been posing the question whether a monetary union can work smoothly without a fiscal union. The Czech Republic has a valuable experience in this respect. After division of Czechoslovakia and after fiscal transfers were stopped, the efforts to maintain a monetary union between Czechia and Slovakia were successful for only five weeks. How long the eurozone will last is the exciting question that every rational economist is asking (Klaus, 2012).

\section{Figure 5}

\section{Structural Deficits in the EU}

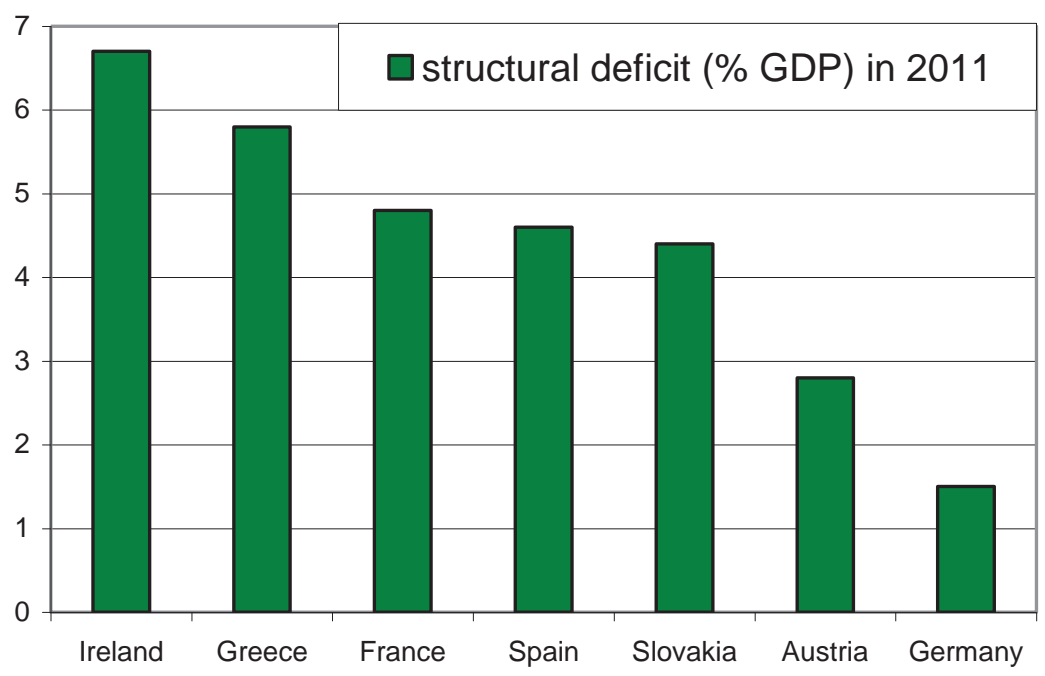

Source: European Commission, 2012 
There is a risk that the structural faults of the eurozone will condemn it to make a choice whether it wants to be a not quite functional federation or a not quite functional currency area. However, this is such a difficult choice that a third alternative, a typically European one, is not out of the question: saying many words, faking a solution to a fundamental problem and trying to buy time. In the established euro-jargon, this is referred to as "getting by". That is the absolutely most costly way (Hampl, 2012).

In December 2011, Nicolas Sarkozy, the French president, admitted that the risk of decomposition of the eurozone was never higher. Angela Merkel, the German chancellor, admitted that euro was not trustworthy (Durdi, Durré, Mongelli, 2012). A new treaty was put through, which provides for automatic sanctions for breach of fiscal discipline, lays down new fiscal rules and debt safeguards and a permanent rescue mechanism ESM (European Stability Mechanism). However, the United Kingdom did not sign the treaty. They do not like the fact that it is heading towards a fiscal union, which means joint examination of state budgets and coordinated implementation of economic policies.

According to the new European fiscal treaty, the structural fiscal deficit should not exceed $0.5 \%$ of the nominal GDP per year. In exceptional cases (for example, during an economic crisis), it would be possible to circumvent this rule. Enforcement of this rule will be overseen by the European Court of Justice. Whoever will not comply will not receive money from the European funds. Fiscal budgets will be subject to Brussels' approval according to the fiscal treaty. Several countries have introduced debt brakes into their constitutions. At present, the Federal Republic of Germany, Austria, Spain, Estonia, Poland and Slovakia have them in their constitutions.

However, the problem with rules set in this way is that some will not regard the deficit of $0.5 \%$ of GDP as the limit but as the permitted goal. The problem of many of the countries using euro is not their current deficit but the amount of their public debt. The measures are largely a repetition of the Maastricht criteria that nobody was meeting. The innovation should be their better enforceability. The sanctions for failure to meet them would no longer be subject to approval by other member states but they would be imposed automatically. However, members would have the option to waive the sanctions. This is not that much different from the current situation (Kuhn, Stockel, 2014).

In October 2012, the permanent rescue fund of the eurozone (European Stability Mechanism - ESM) was launched and is to lend up to 500 billion euro. ESM will be able to directly recapitalise the banks in trouble. The fund will be able to buy the bonds of states in order to decrease their interest rates on the markets. Similarly like its predecessor ESFS, it will also be able to borrow money in order to be able to lend them to the countries in trouble (Maier, 2013).

The euro bonds, which some of the financial markets see as one of the solutions to the debt crisis, have serious pitfalls (Sinn, Berg and Carstensen, 2011). Even if the EU wanted to build a federal state, it would not be meaningful to introduce shared liability for the public debts of the eurozone member states. Even in the USA, which form a single nation, a member state is not liable for the financial management of other states. The missing collective liability for the public debts of individual states is even the reason why the American federalism works (Muellbauer, 2013).

It is improbable that euro will completely collapse and become a thing of the past (Eichengreen, 1993). Too much political capital has already been invested into euro for the governments letting the fruit of their work wither and die. Nevertheless, the system is 
facing a threat of fragmentation because both the stronger and the weaker countries can disconnect themselves from it and re-introduce some form of their own currency that will better correspond to their economic needs.

Departure of some or all peripheral states from the eurozone may not necessarily mean the end of the monetary union; it may "only" result in division into two groups: the Northern one and the Southern one. If the eurozone were really divided into a Northern part and a Southern part, Germany would not remain alone; it would be surrounded by other EU countries from the Northern wing. Germany will not find itself in isolation; it is more likely to become a part of a new monetary arrangement (Marsh, 2009).

\section{Conclusion}

The current eurozone was not created in accordance with the economic theory and rationality as an optimum currency area but it was created according to political priorities as a conglomerate of not quite compatible economies, which were put at the same starting line as a result of having met the (often fictitious) Maastricht criteria. The euro did not have the effect of bringing about convergence of the economic development in the euro zone but, conversely, it lead to its divergence.

The result of the fifteen-year existence of the eurozone is that the economic development started to diverge and the "straight jacket" of the single currency started to crush the individual member countries ever more palpably. While "good weather" prevailed, no visible problem occurred. However, as soon as "bad weather" came in the form of the economic and financial crisis, the non-homogeneity of the eurozone was demonstrated more than clearly.

So much political capital has been invested into the existence of the single currency as the common element of the European Union that, most probably, it will not be abandoned in the nearest future. However, it will continue to exist at an enormous cost, which will be paid by the citizens of the eurozone in the form of low economic growth or stagnation. The relative weakening of the economic performance of Europe will be particularly visible in comparison with the dynamic development in other parts of the world.

\section{References:}

Bagus, P. (2011), "The Tragedy of the Euro." The Independent Review, Vol. 15, No. 4, pp. 563-576.

Bohn, F., Jong de, E. (2011), "The 2010 Crisis Stand-off between France and Germany." International Economics and Economic Policy, Vol. 8, No. 1, pp. 7-14.

Braun, D., Tausendpfund, M. (2014), "The Impact of the Euro Crisis on Citizens's Support for the European Union." Journal of European Integration, Vol. 36, No. 3, pp. 231-245.

Buti, M., Carnot, N. (2012), "The EMU Debt Crisis: Early Lessons and Reforms." Journal of Common Market Studies, Vol. 50, No. 6, pp. 899-911.

Coenen, G., Straub, R., Trabant, M. (2012), "Fiscal Policy and the Great Recession in the Euro Area." American Economic Review, Vol. 102, No. 3, pp. 71-76.

De Grauwe, P., Ji, Y. (2013), "Self-fulfilling Crises in the Eurozone: An Empirical Test." Journal of International Money and Finance, Vol. 34, pp. 15-36. 
Drudi, F., Durré, A., Mongelli, F. P. (2012), "The Interplay of Economic Reforms and Monetary Policy. The Case of the Eurozone." Journal of Common Market Studies, Vol. 50, No. 6, pp. 881-898.

Eichengreen, G. (1993), “European Monetary Unification.” Journal of Economic Literature Vol. 31, No. 3, pp. 1321-1357.

Eichengreen, B. (2011), "The Euro's Never-Ending Crisis." Current History, Vol. 110, No. 734, pp. 91-96.

Feldstein, M. (2012), "The Failure of the Euro: the Little Currency that Couldn't." Foreign Affairs, Vol. 91, No. 1, pp. 105-116.

Feldstein, M. (1997a), “EMU and International Conflict.” Foreign Affairs, Vol. 76, No. 6, pp. 60-73.

Feldstein, M. (1997b), "The Political Economy of the European Economic and Monetary Union: Political Sources of an Economic Liability." Journal of Economic Perspectives, Vol. 11, No. 4, pp. 23-42.

Ferguson, N., Kotlikoff, L. (2000), "The Degeneration of EMU." Foreign Affairs, Vol. 79, No. 2, pp. 110-121.

Friedman, M. (1970), "The Case for Flexible Exchange Rates." in: Friedman, M.: Essays in Positive Economics: Chicago - London, The University of Chicago Press, pp. 157-203.

Giavazzi, F. (2010), Why the Current Account Matters in a Monetary Union: Lessons from the Financial Crisis in the Euro Area. London: Centre for Economic Policy Research.

Gros, D. (2013), "Foreign Debt Versus Domestic Debt in the Euro Area." Oxford Review of Economic Policy, Vol. 29, No. 3, pp. 502-517.

Hampl, M. (2010), “The Euro's Instability Pact." Wall Street Journal, 29 September, p. 13.

Hampl, M. (2012), "European Monetary Integration and a Position of Its Former Hegemon." Politická ekonomie, Vol. 60, No. 6, pp. 707-721.

Janáčková, S. (2004), "Eurozone Expansion." Eastern European Economics, Vol. 42, No. 2, pp. 6-44.

Janáčková, S. (2010), The Eurozone Crisis and the Debt Crisis of the Developed World. Prague: Center for Economics and Politics.

Jones, E. (2009), "The Euro and the Financial Crisis." Survival, Vol. 51, No. 2, pp. 41-54.

Karras, G. (2011), "From Hero to Zero? The Role of the Euro in the Current Crisis." International Advances in Economic Research, Vol. 17, No. 3, pp. 300-314.

Klaus, V. (2012), Europe - The Shattering of Illusions. London: Bloomsbury Publishing.

Klaus, V. (2004), "The Future of the Euro - An Outsider's View." CATO Journal, Vol. 24, No. 1-2, pp. $171-177$.

Kohout, P. (2010), Post-Crisis Finances. Prague: Grada.

Kouretas, G. P., Vlamis, P. (2010), "The Greek Crisis - Causes and Implications." Panoeconomicus, Vol. 57, No. 4, pp. 391-404.

Krugman, P. (2010), "The Spanish Tragedy." New York Times, 5 February 2010.

Kuhn, T., Stockel, F. (2014), "When European Integration Becomes Costly: The Euro Crisis and Public Support for European Economic Governance." Journal of European Public Policy, Vol. 21, No. 4, pp. 624-641.

Lorca-Susino, M. (2010), The Euro in the 21St Century: Economic Crisis and Financial Uproar. Farnham: Ashgate.

Lynn, M. (2010), Bust. Greece, the Euro and Sovereign Debt Crisis. Chichester: Wiley.

Maier, M. J. (2013), "Potential Instruments That the ECB Could Take in Order to Face the Euro Zone Crisis." Equilibrium, Vol. 8, No. 1, pp. 33-48. 
Marsh, D. (2009), The Euro - the Politics of the New World Currency. New Haven, Conn.: Yale University Press.

Muellbauer, J. (2013), "Conditional Eurobonds and the Eurozone Sovereign Debt Crisis." Oxford Review of Economic Policy, Vol. 29, No. 3, pp. 610-645.

Mundell, R. (1961), "A Theory of Optimum Currency Areas." American Economic Review, Vol. 51, No. 4, pp. 657-665.

Mundell, R. (1998), The Euro as a Stabilizer in the International Monetary System. European Conference Center, Luxemburg, December 1998.

Nellis, J., Alexiou, C. (2012), "Is the Euro a Defunct Currency?" International Journal of Economics and Financial Issues, Vol. 2, No. 3, pp. 296-303.

Pavoncello, F. (2011), "One for All, All for One. The Euro in Crisis." World Affairs, Vol. 174, No. 1, pp. 59-70.

Pinera, J. (2004), "Will the Pension Time Bomb Sink the Euro?" CATO Journal, Vol. 24, No. 1, pp. 45-50.

Prokopijevic, M. (2010), “Euro Crisis." Panoeconomicus, Vol. 57, No. 3, pp. 369-384.

Reinhart, C. M., Rogoff, K. S. (2009), This Time is Different: Eight Centuries of Financial Folly. Princeton: Princeton University Press.

Ryan, C. (2011), "The Euro Crisis and Crisis Management. Big Lessons from a Small Island." International Economics and Economic Policy, Vol. 8, No. 1, pp. 31-43.

Sarrazin, T. (2012), Europa braucht den Euro nicht. München: Deutsche Verlags-Anstalt.

Singer, M. (2010), "What the Greek Crisis Means for the Eurozone and for US", Newsletter CEP No. 6/2010.

Sinn, H. W. (2010), Casino Capitalism. How the Financial Crisis Came about What Needs to be Done Now. New York - Oxford: Oxford University Press.

Sinn, H. W., Berg, T. O., Carstensen, K. (2011), "Was kosten Eurobonds?" Ifo Schnelldienst, Vol. 64, No. 17 , pp. 25-33.

Tomšík, V., Šaroch, S., Srholec, M. (2005), "Euro Adoption in the New EU Member Countries Speed Limits on One-Way Road." Eastern European Economics, Vol. 43, No. 2, pp. 5-24.

Vitek, F. (2011), Spillovers from the Euro Area Sovereign Debt Crisis. London: Centre for Economic Policy Research.

Welfens, P. (2011), "From the Transatlantic Banking Crisis to the Euro Crisis?" International Economics and Economic Policy, Vol. 8, No. 1, pp. 15-29.

Wittmann, W. (2011), "Von der Finanzkrise zur Schuldenkrise", Jahrbuch für Wirtschaftswissenschaften, Vol. 62, pp. 40-55.

Whelan, K. (2013), "Sovereign Default and the Euro." Oxford Review of Economic Policy, Vol. 29, No. 3, pp. 478-501.

Wolf, H. (2012), "Eurozone Entry Criteria after the Crisis." International Economics and Economic Policy, Vol. 9, No. 1, pp. 1-6. 